\title{
Modelling the freshwater supply of cisterns in ancient Greece
}

\author{
Patrik Klingborg ${ }^{1}$ (D) Martin Finné $^{1}$ (D)
}

Received: 2 August 2017/ Accepted: 21 December 2017/Published online: 18 January 2018

(C) The Author(s) 2018. This article is an open access publication

\begin{abstract}
In this paper, we model the function of rainwater harvesting cisterns in ancient Greece. The model calculates on a monthly basis: (1) the collected and stored volume of water; (2) the amount of water extracted for individual use; and (3) the potential accumulated surplus available by the end of a month. The potential of the model is explored through two case studies based on material from Olynthos in Thessaly and Dystos on ancient Euboia by running 26 consecutive annual cycles utilizing modern precipitation data from meteorological stations as a proxy for ancient precipitation and precipitation variability. Our results show that cisterns can provide ample amounts of freshwater to households and function as buffers for water stress in shorter (monthly), and longer terms (seasonally, yearly and between years). The two cisterns in this paper yield between 10.7 and $86.6 \mathrm{~m}^{3}$ per annum with a strong variability in collected water volumes within and between years. Yet, this variability is, largely predictable and thus the use of cisterns in ancient Greece should be viewed in the light of predictable variability that required active participation from members of the household to be efficient.
\end{abstract}

Keywords Rain water harvesting · Cisterns - Modelling - Sustainability · Predictable variability · Ancient Greece

Patrik Klingborg

Patrik.klingborg@antiken.uu.se

Martin Finné

Martin.finne@antiken.uu.se

1 Department of Archaeology and Ancient History, Uppsala University, Box 626, 75126 Uppsala, Sweden 


\section{Introduction}

A reliable freshwater supply is imperative for human survival. Providing this can, however, be complicated, especially in semi-arid environments with a distinct wet and dry season, and where groundwater resources may be under pressure or unavailable (Döll 2009; UNESCO 2012). In the Mediterranean region today, pressure on freshwater resources is high and expected to increase considering projected climate change and growing populations (UNESCO 2012; Collins et al. 2013). Understanding issues around freshwater supply in the region is therefore of crucial interest. The Mediterranean area offers a unique opportunity to study issues of freshwater supply in a longer perspective given its long history of human activity and relatively well investigated archaeological record. However, our understanding of water supply in the ancient Mediterranean world is skewed and incomplete as studies have focused almost exclusively on monumental infrastructure, mainly aqueducts and fountains (Klingborg 2017). Yet, basic installations such as wells and cisterns formed the primary water sources for the population in the ancient world with a small number of exceptions during the Roman period (Hodge 2000a; Klingborg 2017).

Cisterns can utilize rainwater harvesting $(\mathrm{RWH})$ in order to collect and provide freshwater. Although the contribution may vary, the method is a sustainable water source with the advantage of being available on the spot for everyone (Lange et al. 2012). In this paper, we develop and run a model to test the function of two ancient cisterns in Greece, one at Olynthos and the other at Dystos, as providers of freshwater for households on a monthly basis (Fig. 1). This enables us to exemplify how these installations functioned and highlight monthly and annual variability as well as variability between years. For the modelling, we use modern monthly precipitation data. While this data does not provide

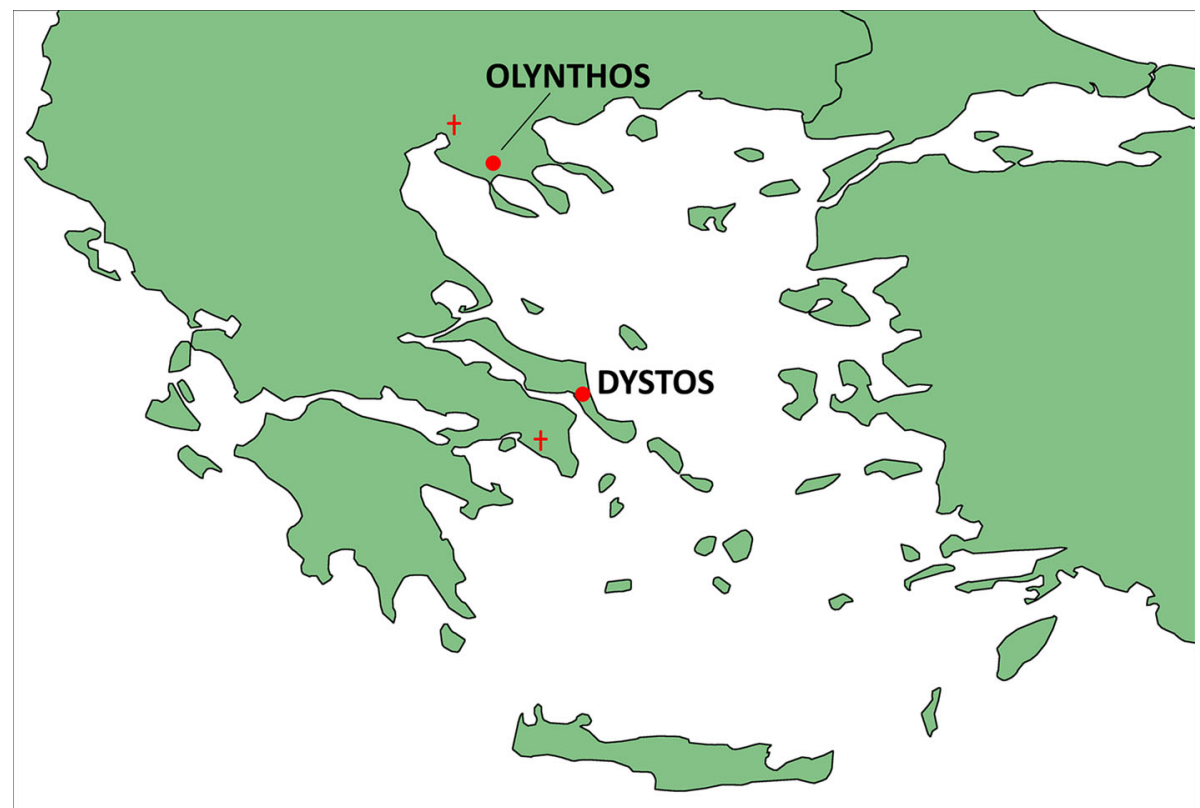

Fig. 1 Map showing the location of the cisterns used as case studies in this paper (circles) and the location of the meteorological stations (crosses) from which precipitation data was used in our model 
actual figures for past precipitation, it can be used as an analogue to capture the variability in freshwater supply provided by ancient cisterns. It is able to show, for instance, how they may have functioned during individual or consecutive dry years. By working with monthly data, it is possible to achieve an understanding of water supply, and variability in supply, on time scales relevant to human subsistence.

\section{Background}

The study of ancient water supply systems has been an important part of Classical studies ever since the discipline was founded, primarily because of the attraction of Roman aqueducts. Fountains have also received much attention as they belong to the category of elaborate public infrastructure (Hodge 2000a; Klingborg 2017). The dominating approach in the study of these structures has been power, memory and monumentality. During the last decades, there has been an increased interest in questions related to water management and sustainability, often in connection to the increasing awareness of the challenges to modern society in the face of climate change and population growth (Antoniou et al. 2006; Mays et al. 2013; Antoniou et al. 2014).

The modern understanding of ancient water supply systems is, however, severely limited because there has been a lack of studies on the less monumental but more common water sources, primarily wells and cisterns (Hodge 2000a). There are, unfortunately, no estimates on how common the various water sources were in relation to each other, but cisterns and wells must have numbered in the tens, or hundreds, of thousands, while only 95 fountain houses were accounted for in an inventory study covering the area of modern Greece (Glaser 1983; Klingborg 2017). The issue can be exemplified by how the 149 cisterns found in Pergamon are treated in unusual great depth of 25 pages in a 350-page volume about the city's water supply, which is still less than any of the individual aqueducts (Garbrecht 2001). Around the Agora in Athens at least 150 cisterns and 230 wells have been found, in contrast to a handful of fountains which have been treated in much more detail (Sparkes and Talcott 1970; Camp 1977; Klingborg 2017). Similarly, Nicholas Cahill, in his otherwise excellent study of ancient Olynthos, only mentions the two fountain houses under the heading Water supply, while the fact that cisterns have been found in 15\% of the excavated houses is omitted (Cahill 2002; Klingborg 2017, cisterns nos. 289-307). In essence, the importance of cisterns and wells has been severely underestimated. We argue that it is impossible to explore the ancient water supply system as a whole, and therefore to understand how it is related to factors such as climate change, social development, demographic variation, technological advance and economic prerequisites, unless we obtain a more holistic understanding of the water supply systems, including these installations. In this article, a cistern (Fig. 2) is defined as a statically situated waterproof container constructed above or below ground to store water. The water in a cistern is received from an external source, most commonly rainwater, and channelled into it. Cisterns are, however, not intended to receive a constant inflow, because they are not primarily designed to facilitate a continuous outflow.

In the ancient Greek world cisterns were primarily used between c. 400 and 50 BC, and in this period they were found in practically all cities and settings ranging from private houses and farms to local sanctuaries and international cult places (Klingborg 2017; see also Brinker 1990). Cisterns in ancient Greece were constructed in a number of shapes 


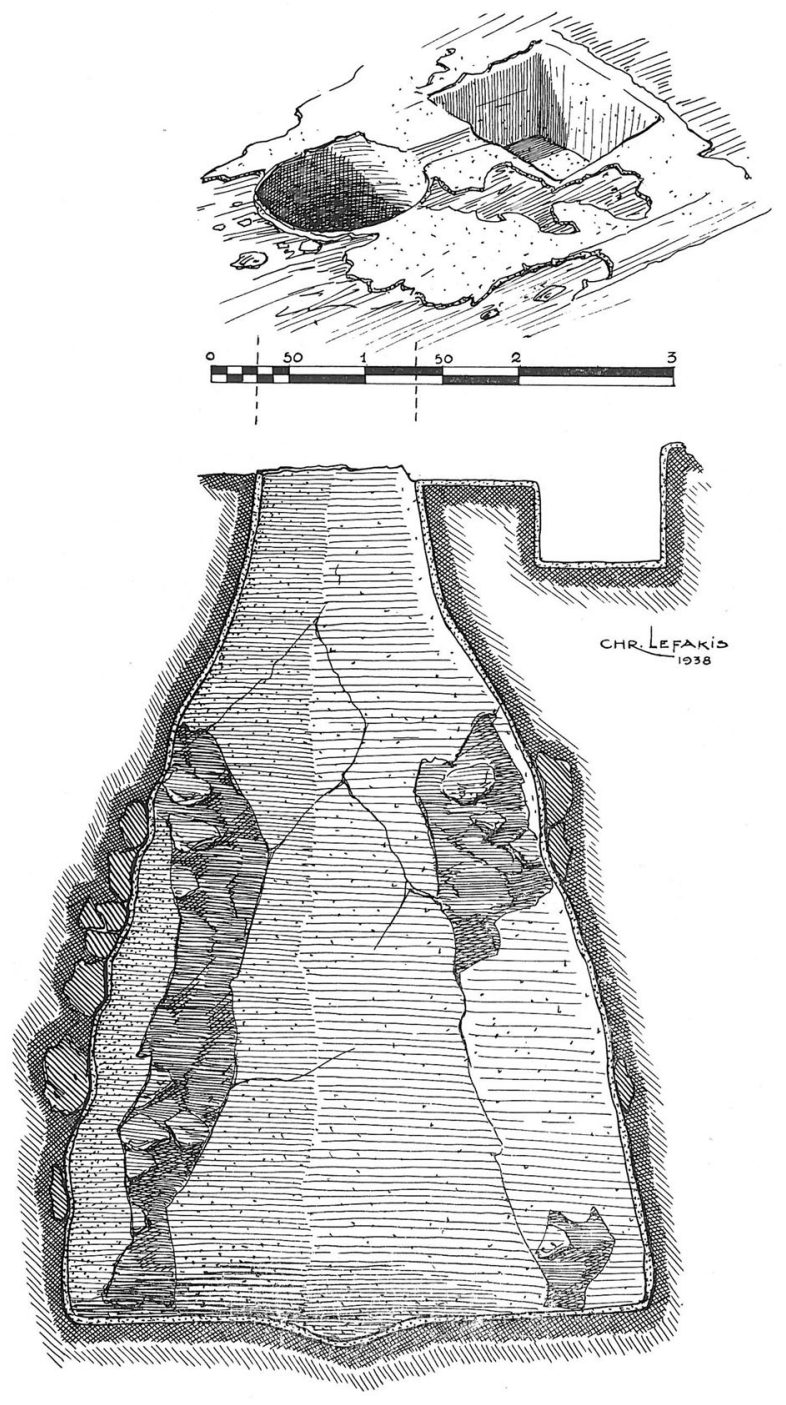

Fig. 2 Sketch of cistern in house Av5 in Olynthos (Robinson 1946). This cistern is similar to the cistern in house Bvi2 in Olynthos, one of the cisterns under consideration in this paper. Various other versions of cistern shapes were also used in antiquity (Klingborg 2017)

typically in natural or artificial cavities or by masonry. These techniques could also be combined. The vast majority of cisterns were made waterproof by using a lining.

Some attempts have been made to calculate how much water cisterns would make available in antiquity. Crouch (1984) reported that the excavators at Morgantina on Sicily were under the impression that the volume of water made available was closely connected to the volume of the cistern. Garbrecht crudely calculated the water made available by the 149 cisterns at Pergamon based on modern average precipitation. His work, however, was on a city-wide scale and calculated on the combined volume of all cisterns in the city, with the assumption that $70 \%$ of the area of the city was roofed and that could be considered the 
catchment area, and a small loss through evaporation and leakage (Garbrecht 2001; see also Wellbrock 2016 and Brinker 1990). Garbrecht's work was later followed by a more detailed study by Wellbrock (2016) on individual cisterns in Pergamon based on daily and yearly rainfall data. Similarly, Connelly and Wilson explored the potential of a cistern on the island Geronisos off Cyprus based on modern average precipitation, a clearly limited catchment surface, loss to evaporation and use (Connelly and Wilson 2002). Yet, their study presents a very special case as the cistern was situated on a small island with no permanent habitation. The situation was, therefore, not representative for how cisterns were used in domestic contexts where the vast majority are found (Klingborg 2017). In a study from the island Pantelleria, located southwest of Sicily, Mantellini (2015) discusses the use of ancient cisterns to supply freshwater in a waterless environment using a model set up similar to Connelly and Wilson (2002). Mantellini's work is based on a model that uses average monthly rainfall values and a static catchment surface based on the oldest dammuso, a traditional rural living unit, on the island. For a further similar modelling example see Keilholz (2014) on cisterns in Gadara/Umm Qais in Jordan. The present study contributes a more complex model using actual precipitation figures rather than average data, in combination with detailed information from archaeological remains and provides results for cisterns in settings which are more representative and applicable for a wider archaeological material.

\section{Building the model}

To study the function of ancient cisterns we have designed a model based on RWH, that on monthly basis calculates: (1) the collected and stored volume of water, (2) the amount of water extracted for individual use, and (3) the potential accumulated surplus available by the end of each month. Our model is divided into a supply side and an extraction side; surplus is the difference between supply and extraction when positive, while the accumulated surplus denotes any water left in the cistern by the end of a month. Accumulated surplus can thus exist without surplus in any given month (Fig. 3). For the supply side, the model uses precipitation amounts, the available catchment surface and the volume of water lost to evaporation and other factors (the so-called runoff-coefficient). This is similar to model set-ups used to analyse modern RWH systems (e.g. Farreny et al. 2011; Lange et al. 2012) and ancient cisterns (e.g. Garbrecht 2001; Connelly and Wilson 2002; Mantellini 2015). The water collection surface is typically a roof-top from which the water is led through pipes and conduits to the cistern. The water is stored in a cistern with a maximum volume which cannot be exceeded. The extraction side of the model is represented by the volume of water drawn from the cistern per person per day (Fig. 3). Details regarding both sides are outlined below.

\section{Supply side}

The primary source of water for cisterns was rainwater as suggested by ancient authors, 19th- and 20th-century explorers and recent research (Vitr. De arch.; Diod. Sic.; Schick 1878; Masterman 1918; Robinson and Graham 1938; Biernacka-Lubańska 1977; Brinker 1990; Sazakli et al. 2007; Mays 2010; Van Liefferinge 2013). The volume of a cistern marks the maximum volume that could be stored at any one point. Commonly cisterns in ancient Greece had a volume of $10-30 \mathrm{~m}^{3}$, but volumes up to $600 \mathrm{~m}^{3}$ exist (Klingborg 


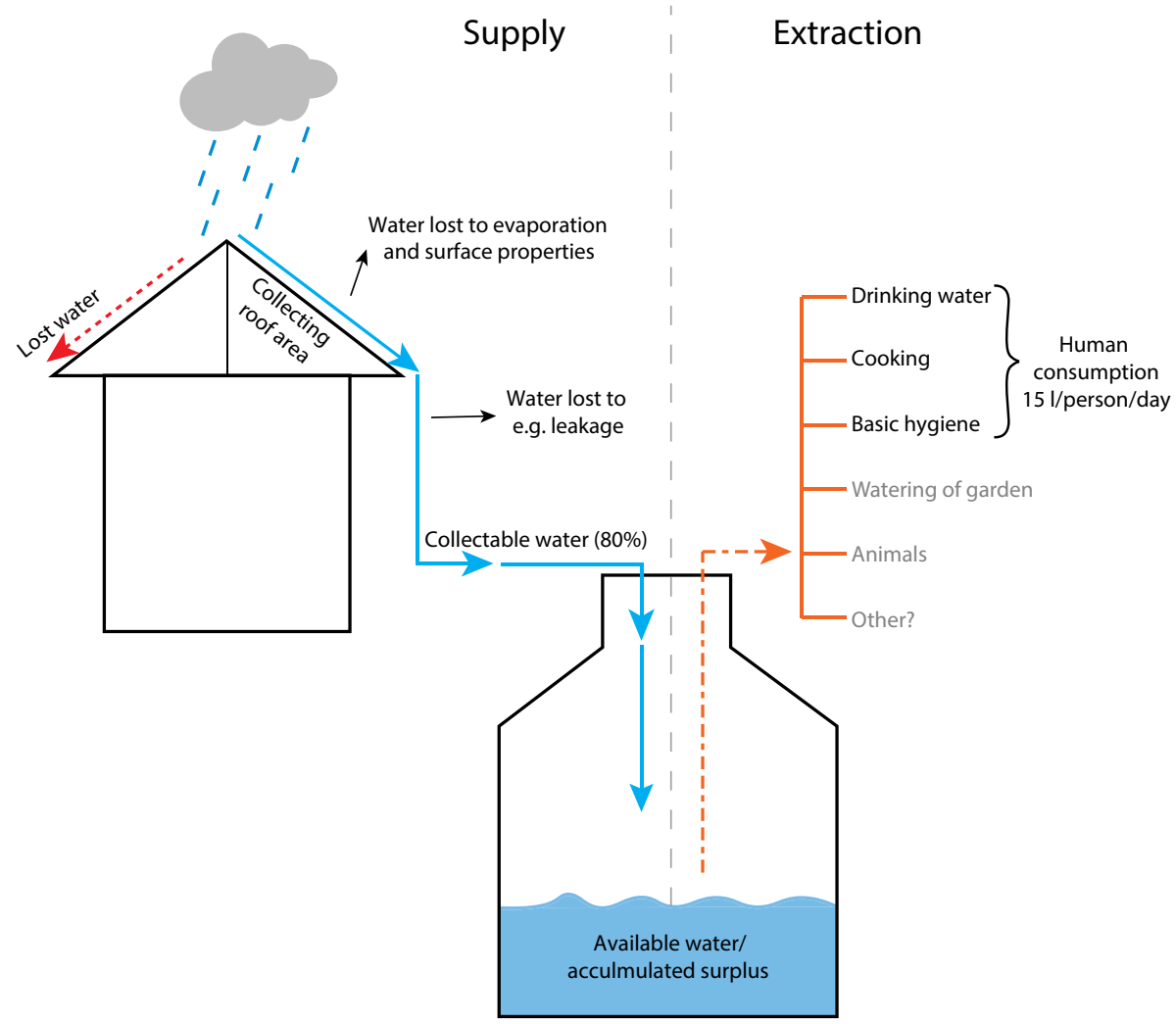

Fig. 3 Outline of the RWH model designed for and applied in this paper, showing the various components affecting: (1) the volume of collected water (supply side); (2) the volume extracted from the cistern (extraction side); and (3) the available volume of water in the cistern as a function of supply and extraction

2017, cistern no. 358). However, the cistern volume does not reflect the volume of water available for usage, because this depends on how much water that was collected.

The area available for rainwater harvesting is unique for each cistern and can be elucidated based on the archaeological remains, when well preserved. Water collection is typically limited to roof tops in modern urban contexts, and this was probably also the case in ancient times considering the presence of refuse on the ground (Farreny et al. 2011; Klingborg 2017).

Although there are several studies about past climate in the region, there are few reconstructions of absolute rainfall amounts reaching beyond the instrumental period and none of sufficient resolution for this study. Therefore, we rely on modern precipitation data from meteorological stations. Palaeoclimate data from the eastern Mediterranean suggest the period between 400 and $50 \mathrm{BC}$ is one with substantial regional differences, in common with other periods. Palaeoclimate data from the Peloponnese, southwest Turkey and the Albanian coast suggest this area was generally wetter in the interval 400 to $50 \mathrm{BC}$ compared to the centuries just before and after (Eastwood et al. 2007; Roberts et al. 2008; Zanchetta et al. 2012; Leng et al. 2013: Finné et al. 2014; Boyd 2015). However, areas farther in the eastern Mediterranean, Anatolia and the Levant, seem to have been generally drier in this interval (e.g. Finné et al. 2011; Dean et al. 2015). 
Some of the water collected from the roof area was lost due to factors such as evaporation, leaking conduits and pipes, the slope of the roof, wind direction and the smoothness of the roof (Farreny et al. 2011). The loss of water has been estimated between 5 and 30\% in modern studies (Connelly and Wilson 2002; Thomas and Martinson 2007; Farreny et al. 2011). The loss from terracotta roofs in Spain, representing a similar roof material and environmental setting as our study, found a water loss of $16 \pm 1 \%$ (Farreny et al. 2011). Based on these factors and figures we use a slightly more conservative loss factor of $20 \%$ to account for a rougher terracotta surface in antiquity than today and loss of water from spill and leakage during transportation. The same figure was used by Mantellini (2015) for the study on Pantelleria.

A central assumption in this study is that cisterns in ancient Greece operated on a cyclic principle where they were emptied for cleaning and maintenance once per year. Although there is no direct archaeological evidence for cleaning this assumption is supported by a c. $200 \mathrm{BC}$ law from Pergamon that records that cisterns had to be cleaned and repaired once a year in the month of Pantheios, possibly taking place at the transition between autumn and winter (inscription Orientis Graeci inscriptiones selectee 483; Kolbe 1902; Klaffenbach 1954; Austin 2006; Saba 2012). There are also inscriptions from Delos testifying to cleaning work for $\varphi \rho \hat{\varepsilon} \alpha \tau \alpha$, a word denoting both cisterns and wells (inscriptions ID 290; ID 338). In the late 19th and early 20th century scholars exploring the Levant describe how cisterns functioned and were used in Jerusalem, stressing that cisterns must be periodically cleaned, along with the need to keep the house and collection surfaces free of pollutants (Schick 1878; Masterman 1918). Still today, municipal cisterns on the island of Kefalonia are cleaned in September every year before the rainy season begins (Sazakli et al. 2007). To allow for cleaning the model assumes that the cistern was emptied of any accumulated surplus at the end of October annually. This means, the model assumes that the volume in the cistern is zero at the beginning of each November, marking the start of each annual cycle. This point in time was chosen based on the evidence presented above and the fact that the vast majority of precipitation in Greece falls between November and April. Emptying of the cistern was thus facilitated by naturally occurring low water levels following the dry season.

\section{Extraction side}

The water used by the household must also be taken into account because this would reduce the available volume of water in a cistern. This volume is, like the precipitation and size of the water collection surface, dependent on the specific circumstances: how many individuals depended on the cistern; how much water they used; and whether or not any further water sources were available. Water from a cistern may also have been used for production, keeping animals or urban agriculture.

In this study, we have assumed that water from the cisterns was used by seven individuals. This figure is based on Robinson and Graham's estimate of six to eight inhabitants per household in Olynthos, excluding slaves (Robinson and Graham 1938). The volume of water used on average by each individual per day is estimated to 151 . This figure is static in the model, i.e. there is no adjustment in the amount of water used when water levels drop. We base our estimate on figures from WHO regarding the volume of water needed to remain healthy. Although this volume varies widely the WHO estimates that 7.51 per day per person is sufficient for hydration and incorporation into food (WHO 2011). We have doubled the estimate from WHO to allow water for basic hygiene needs and possibly other activities. It is estimated by WHO that 201 per person per day allow for basic hygiene, but 
that this may be compromised (WHO 2011). A previous study concerning a cistern on the island Geronisos near Cyprus by Connelly and Wilson (2002) estimated the used volume to 101 per person per day (based on an unreferenced figure of 51 per person per day from WHO). Five litres per person per day, however, marks the limit of what WHO estimate to be enough to remain healthy (WHO 2011). Our estimate is also well in line with figures for water use during the nineteenth and twentieth centuries in Europe. In Paris and London in 1823, 14.11 was used per individual per day, and in Liverpool in 1835 it was16.6 1 (Hodge 2000b, adapted from Forbes 1955). Mantellini (2015) approaches the consumption from the other end, and calculates the possible daily consumption volume based on the modelled annual volume collected by the cistern to arrive at 361 per day per household.

Consumption of cistern water is a much debated topic among modern scholars. One issue is that the ancient literary sources are often contradictory. Secondly, the ancient inhabitants of the Greco-Roman world had no scientific way to determine the quality of different water sources and their verdicts are therefore highly subjective (Vitr. De arch. 8; Plin. HN. 31; Ath. 2; Brinker 1990; Garbrecht 2001). Thirdly, modern standards are misleading as we are used to freshwater of unprecedented good quality and quantity (Brinker 1990; Garbrecht 2001). Yet, evidence from ancient, and late 19th and early 20th century, sources show that cistern water was consumed (Ath. 2; Schick 1878; Masterman 1918). Some cities also seem to have relied exclusively on cisterns in antiquity for long periods, e.g. Pergamon and Termessos (Brinker 1990; Kürkcü 2014, conference paper 'Termessos - Valley of cisterns' at De Aquaeductu Atque Aqua Urbium Lyciae Pamphyliae Pisidiae. The Legacy Of Sextus Julius Frontinus, Antalya, 31. Oktober-9. November 2014).

\section{Modelling case studies}

The above outlined model is tested in two case studies from two domestic buildings with cisterns: house Bvi2 at Olynthos in Northern Greece and house $\mathbf{J}$ at Dystos on Euboia, Central Greece (Fig. 1). The basic requirement in the selection process was that both the available roof area and volume of the cistern were known, a rare combination which severely limits the potential cases. The selected case studies represent, to our knowledge, the best examples of this combination from ancient Greece. In addition to this, the houses are situated in distinctly different areas of the Greek world, providing a wide geographic coverage, with, for example, different climates.

House Bvi2 at Olynthos in northern Greece covers an area of $296 \mathrm{~m}^{2}$, of which $162.5 \mathrm{~m}^{2}$ could be used to collect rainwater. This is based on Cahill (2002), assuming that $98 \mathrm{~m}^{2}$ of the roof $(17.2 \times 5.7 \mathrm{~m})$ sloped away from the cistern, $35.3 \mathrm{~m}^{2}$ constituted a courtyard $(7.5 \times 4.7 \mathrm{~m})$, and $162.5 \mathrm{~m}^{2}$ collected water (three roofed areas, measuring $17.2 \times 4,7.5 \times 7.5$ and $5 \times 7.5 \mathrm{~m})$. The cistern has been calculated to hold a volume of between 23 and $26 \mathrm{~m}^{3}$ by Robinson and Graham (1938); our calculations are based on $24.5 \mathrm{~m}^{3}$.

Private water sources (i.e. wells and cisterns) were fairly rare in Olynthos. Cisterns are found in c. $15 \%$ of the houses, and no wells have been attested. Nevertheless, the inhabitants of house Bvi2 would also have had access to a number of other water sources, which may have supplemented the cistern. A fountain house was situated c. $75 \mathrm{~m}$ away, at the east side of the city's Agora, and this was probably frequently used by the city's inhabitants as indicated by the many amphora toes found there (Cahill 2002). A second 
fountain house was found a little more than half a kilometre away, on the east side of the so-called South Hill. Additionally the river Resetnikia, flowing west of the city and c. 30-35 m below the so-called North Hill where house Bvi2 was situated, may also have been used although little water flow there in the summer months and it may have been polluted as other water courses during antiquity (Cahill 2002).

House J at Dystos on Euboia covers an area of c. $217.5 \mathrm{~m}^{2}$, of which $118.5 \mathrm{~m}^{2}$ could be used to collect rainwater. This is based on the roofs indicated in Hoepfner (1999), including the areas interpreted as an oikos, the central room in a Greek house, and a thalamus, inner room $\left(67.5 \mathrm{~m}^{2}\right)$, the area over the room interpreted as a stable $\left(32 \mathrm{~m}^{2}\right)$ and the area over the rooms interpreted as a chamber and toilet $\left(19 \mathrm{~m}^{2}\right)$. The cistern can hold a volume of between 30 and $40 \mathrm{~m}^{3}$; our calculations are based on $35 \mathrm{~m}^{3}$ (Hoepfner 1999).

Dystos is considerably smaller than Olynthos and less is known about the water supply in the city. Beside the cistern in house J, two more, considerably larger ones, have been found (Klingborg 2017, nos. 273 and 274), both of which were probably public in nature rather than domestic. Exactly how such a public cistern would contribute to the private water supply of the inhabitants is unknown; it may have been used during moderate droughts, or only for serious emergencies. To the west of the city a lake or swamp is situated, but the quality and quantity of the water during antiquity is unknown, especially during summer (Luce 1971). It, thus, remains unclear what other water sources the inhabitants of house $\mathbf{J}$ at Dystos could supplement the cistern with, if needed.

Monthly meteorological data was acquired through the NOAA Climate Data Online ${ }^{1}$ tool for Thessaloniki Mikra (1964-2016) for the Olynthos case study, and for Athens/ Hellinikon (1955-2016) for the Dystos case study (Fig. 1). The monthly precipitation data contain gaps; we therefore selected the longest period of uninterrupted data available from both stations to create a consecutive monthly time series for 27 years, covering 312 months divided into 26 cycles (i.e. November to October) from 1973/74 to 1998/99. The meteorological station in Thessaloniki Mikra is located approximately $40 \mathrm{~km}$ SE from Olynthos and is expected to provide a good picture of the rainfall situation there. In the other case, the meteorological station in Athens/Hellinikon is located approximately $65 \mathrm{~km}$ to the SW of Dystos, and the meteorological data is likely to underestimate the rainfall amounts in and around Dystos, considering that the average annual rainfall recorded at this station is around $100 \mathrm{~mm}$ lower than for the stations at Skyros (30 km to the NNE of Dystos) and Tanagara (50 km to the $\mathrm{W}$ of Dystos). These stations, however, do not provide the same amount of data as the Athens/Hellinikon station. To further investigate variability in the collected water volumes we analyse the full rainfall data series for both meteorological stations (i.e. 1955-2016 and 1964-2016) for the wettest and driest cycles on record as well as calculate the mean and median rainfall amounts, based on years providing data for all months.

\section{Results-model output}

The modelling output shows that the collected water volume, the surplus and the accumulated surplus, in the cisterns was variable between months and years (Figs. 4, 5). There are also geographical differences between Olynthos located in the wetter northern part of Greece and Dystos off the generally drier southeast mainland. In Dystos the total annual collected water volume varies between $\sim 10.7 \mathrm{~m}^{3}$ and $\sim 56.8 \mathrm{~m}^{3}$, with a mean

\footnotetext{
${ }^{1}$ https://www.ncdc.noaa.gov/cdo-web/. Accessed on 27/06/17.
} 

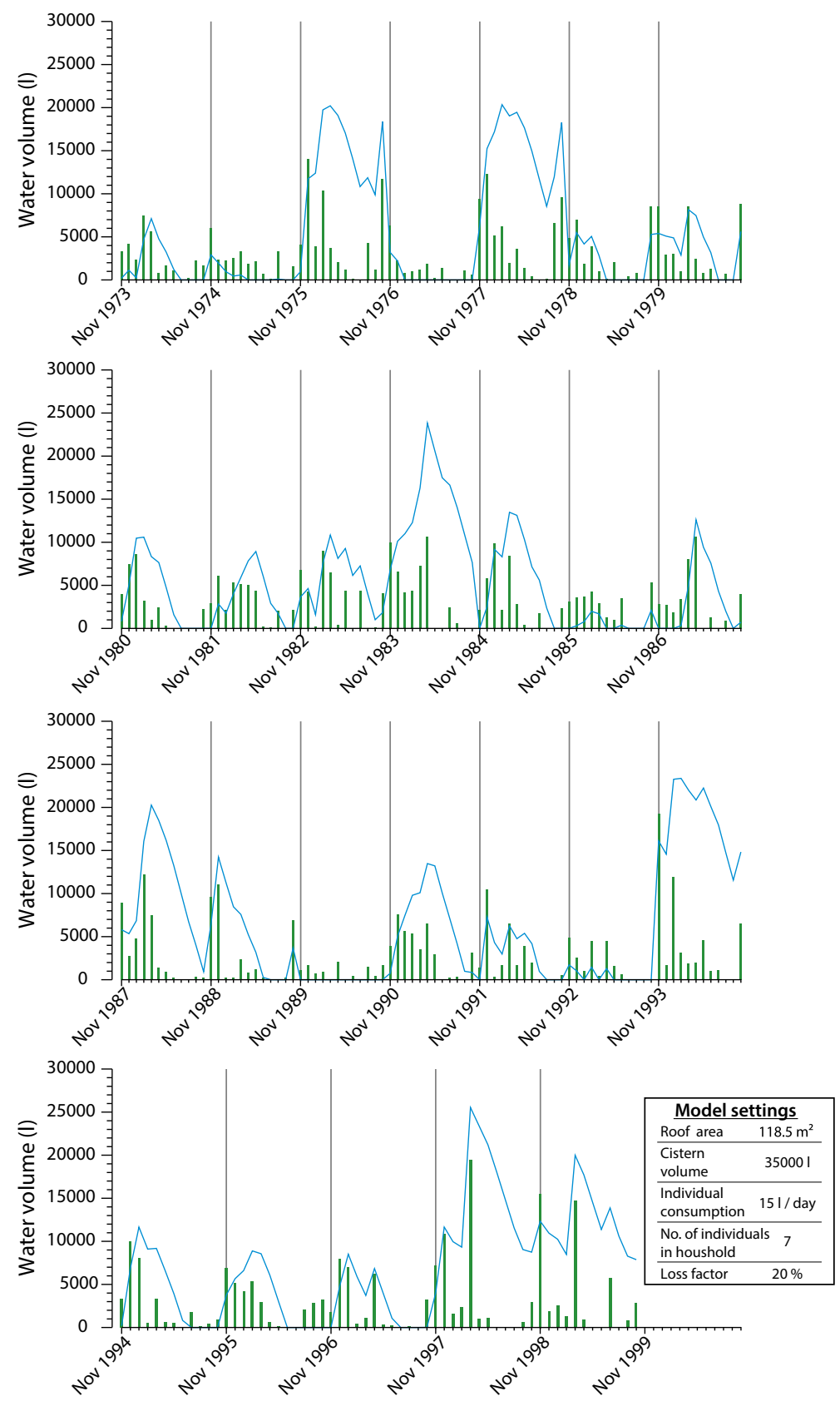

Fig. 4 Model output for the 26-cycle trial period for Dystos highlighting the variability in monthly collected water volumes. Bars (green) show collected water volume for each month during the trial period. Lines (blue) show the accumulated surplus volume at the end of each month (i.e. how much water that is left in the cistern by the end of each month). The accumulated surplus is reset between October and November each year (grey vertical lines) marking the end of each cycle, to allow for cleaning of the cistern. Box in lower right corner show modelling setting producing the results visualized in the figure 

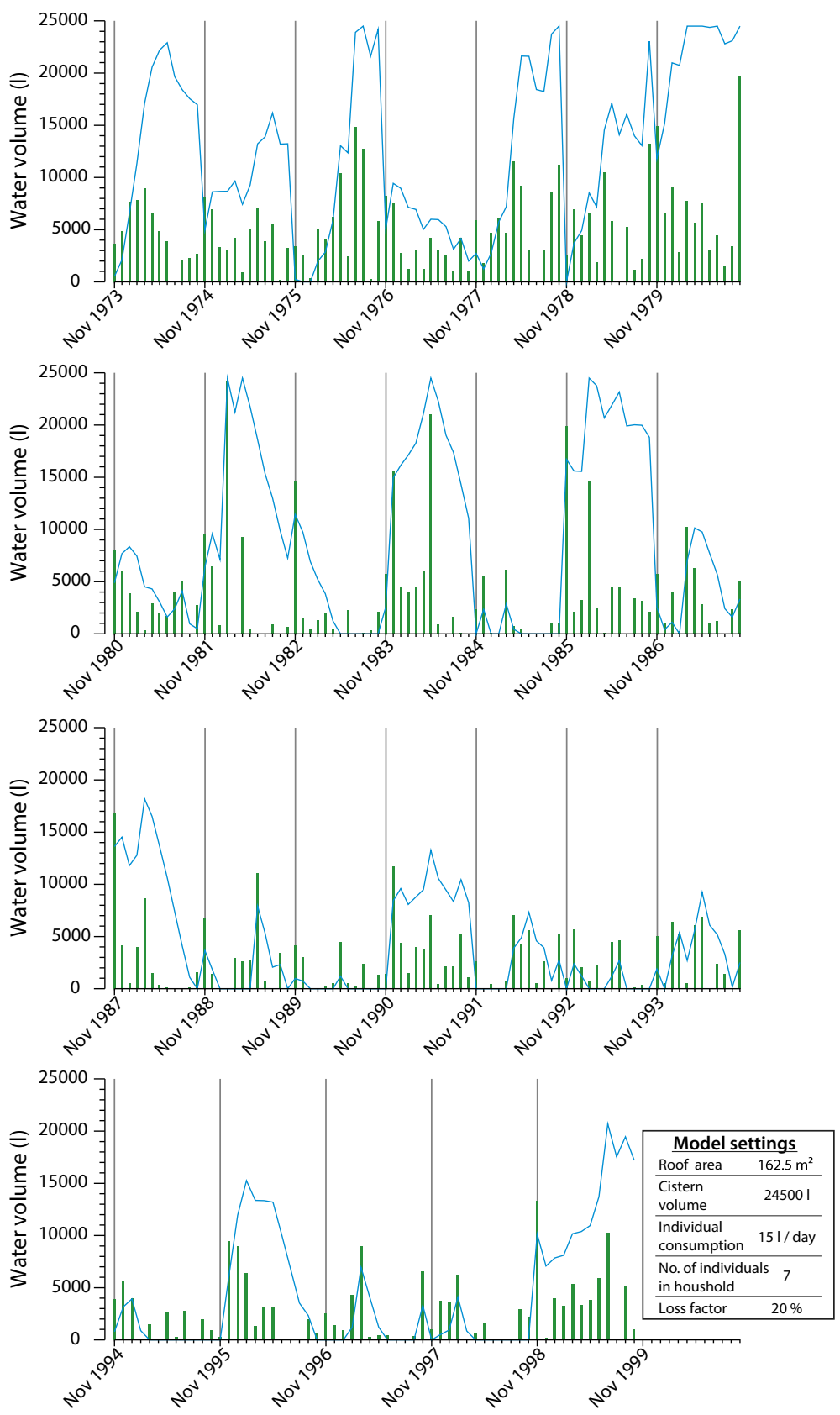

Fig. 5 Model output for the 26-cycle trial period for Olynthos highlighting the variability in monthly collected water volumes. Bars (green) show collected water volume for each month during the trial period. Lines (blue) show the accumulated surplus volume at the end of each month (i.e. how much water that is left in the cistern by the end of each month). The accumulated surplus is reset between October and November each year (grey vertical lines) marking the end of each cycle, to allow for cleaning of the cistern. Box in lower right corner show modelling setting producing the results visualized in the figure 
of $\sim 35.3 \mathrm{~m}^{3}$. In Olynthos the annual collected water volume varies between $\sim 16.9 \mathrm{~m}^{3}$ and $\sim 86.6 \mathrm{~m}^{3}$ with a mean of $\sim 42.9 \mathrm{~m}^{3}$. On average $80 \%$ of the annual water volume in Dystos, and $63 \%$ of the water in Olynthos is collected between November and April. This difference is further underpinned by our choice of meteorological station for modelling Dystos and the results reflect the more genuine Mediterranean climate of the meteorological station in Hellinikon/Athens.

During our trial period water in Dystos lasts throughout the whole cycle (i.e. November to October) in $35 \%$ of the cases, i.e. 9 cycles (of 26 in total) have a continuous accumulated surplus, meaning water was available in the cistern throughout the full cycle (Fig. 4). Of the 312 months in our trial period, 207 months (66\%) do not produce a surplus (i.e. collected and stored less than the $~ 32001$ extracted for use each month) and in 89 months (29\%) there is no water left in the cistern by the end of the month in Dystos. A number of particularly dry cycles inflate this number; $1976 / 77$ and $1989 / 90$ account for nearly $25 \%$ of the months when there was no water left in the cistern. Our model shows that in Dystos no water is collected in $14 \%$ of the total months in our trial period (i.e. 43 of 312 months). However, in $65 \%$ of these cases there is water available in the cistern from preceding months (Fig. 4).

In Olynthos, the model results show that in $42 \%$ of the cycles (11 of 26) there is a continuous accumulated surplus throughout the year (Fig. 5). In $62 \%$ of the cycles there is no or just one month without water left in the cistern by the end of the month. Approximately $58 \%$ ( 180 of 312 ) of the months do not produce a surplus, and in $24 \%$ of the months (75 of 312) there is no water left in the cistern by the end of the month in Olynthos. Similarly to Dystos this number is inflated by a small number of particularly dry cycles. Fourteen percent of the months (43 of 312) in Olynthos do not collect any water, but in $61 \%$ of these cases there is water available in the cistern from preceding months (Fig. 5).

Running the model with consumption reduced to 51 per person per day provides a vastly different result. Under this scenario, the cistern in Dystos runs dry by the end of the month (i.e. no water left in the cistern) only on four occasions, all of which occur during the driest cycle on record 1989/90. In Olynthos, using the same model setting, the cistern runs empty six months of the 312 months covered by the trial period. Of these 6 months three are consecutive: January-March during the 1991/92 cycle.

The extended variability analysis incorporating all rainfall years explore rainfall variability over the full period for which precipitation data is available (Fig. 6). Although the wettest and driest cycles on record occur within the trial period, the calculations of mean and median precipitation are based on the full precipitation data series. During the wettest cycles on record (1979/80 in Olynthos and 1975/76 in Dystos) the cistern in Olynthos is almost full throughout the entire cycle whereas the water collected in the cistern in Dystos provided an accumulated surplus each month, but the cistern was never more than $60 \%$ full (Fig. 6). During the driest cycle on record (1989/90 in both Olynthos and Dystos) the cistern in Olynthos would have collected $\sim 17,0001$ of water, provided a surplus in two months and built up a small accumulated surplus during three months of the cycle whereas the cistern in Dystos would have collected $\sim 11,0001$ but not produced any surplus. However, if water use is reduced to 51 per person per day during the driest cycle on record the cistern in Olynthos builds up an accumulated surplus in all months. In Dystos 5 months produce a surplus and there is a small accumulated surplus during 7 months of the cycle (Fig. 6). There is a noticeable difference in collected water volumes between the median and mean rainfall amount scenarios highlighting the strong variability in rainfall amounts (Fig. 6), indicating that the mean rainfall is not a useful way to approach this type of modelling. 

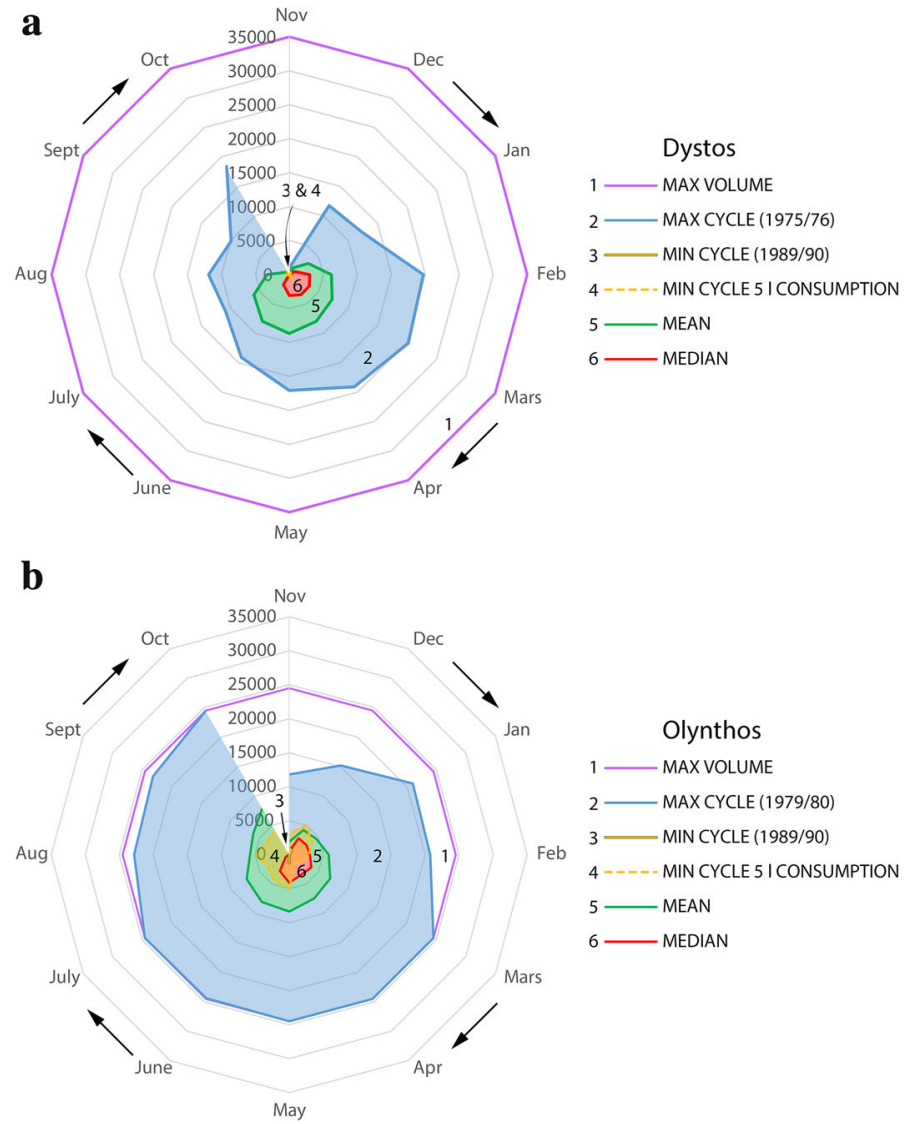

Fig. 6 Circular graphs showing the accumulated surplus volume at the end of each month in one individual cycle in the cisterns in Dystos (a, upper) and Olynthos (b, lower): during the wettest cycle on record (1975/ 76 and 1979/80) (blue lines, no. 1); during the driest cycle on record (1989/90) (yellow lines, no. 3); and the driest cycle but with consumption reduced from $15 \mathrm{l} /$ person/day to $5 \mathrm{l} /$ person/day (dashed yellow lines no. 4), and using the mean (green lines, no. 5) and median (red lines, no. 6) precipitation amounts calculated from the meteorological stations in Athens/Hellinikon (period: 1955-2016) and Thessaloniki Mikra (period: 1964-2016). Purple lines (no. 1) indicate the maximum volume the cistern could hold

\section{Discussion}

The results from the model show that the collected volumes in the cisterns are highly variable both between months and years. Nevertheless, our results show that cisterns under modern rainfall conditions can provide ample amounts of water to a household and in many cases also build up accumulated surpluses lasting throughout parts of or the entire dry period of the year (Figs. 4, 5). Differences in collected volumes between the two case studies can be explained by the difference in collection surfaces, since rainfall amounts during the trial period at the two meteorological stations are similar. The surface in Dystos is $\sim 30 \%$ smaller than in Olynthos, yet the cistern in Dystos is $40 \%$ larger than the one in Olynthos. From modern meteorological data it is clear we underestimate the rainfall amounts in Dystos, but it does not seem realistic that this is enough to account for the 
discrepancy. With the current information in hand, it is not possible to constrain the reason for this discrepancy, but a number of explanations can be conceived: it could have rained substantially more in the past; the cistern had additional collection surfaces that we are unaware of or it was filled from other sources; it could also be that the size of the cistern functioned as a socio-economic statement.

The variability in the collected water volumes in cisterns both between months and years would to some extent have been predictable. The first order control on the predictability of the variability is the volume of the cistern. The cistern cannot contain more water than its maximum volume. The modelling results show that the cisterns are completely filled only rarely; $\sim 1 \%$ of the months, during our trial period indicating that the potential storage volume does not reflect the available water volume at any single point in time. During the vast majority of months, the water level is below half the potential storage capacity. This prompts the question of how the volume of a cistern was decided upon when constructing one. Were cisterns intentionally constructed to be able to hold a volume larger than they were expected to receive and to what degree did the owner of a cistern know how much water it would make available before it was constructed? This must have been a critical issue before cisterns became commonplace, and early adopters must have taken a considerable risk in constructing a cistern given the high cost (Klingborg 2017). The second order control on the variability in volume is the seasonality of rainfall, which was probably well-known and, as far as the paleoclimate evidence shows, also regular in the past (e.g. Arist. Mete. 346b-347a; see also parapegma in Biswas 1970). The third order control on the collected water volume is the variability in rainfall between years. This cannot have presented anyone living in this type of environment, in the past or present, with a surprise. With these three factors taken together we suggest the cisterns should be viewed in terms of what may be termed predictable variability.

This predictable variability means that relying on a cistern as the primary water supply would require active participation, where neither too much nor too little water was used at any given time. If water levels were not managed there is the risk of overflow in a relatively short time span, for example in Olynthos in the end of the cycle 1978/79 where the near full cistern receives almost enough water to fill it once again in October (Figs. 5, 6). Such overflow would not only allow contaminants to enter the cistern, but could also risk undermining walls and destroy property. Not using or managing a cistern was thus not an option once it was constructed unless water was diverted. The water made available by using a cistern was also distinctly finite as a cistern does not continually generate water like other water sources. There was a need to manage the water level in such a manner as to ensure a minimum supply for the rest of the year. Using a cistern without foresight could therefore have had serious consequences, both because it could overflow and damage structures and because without conservative consumption one would run the risk of emptying the cistern early in the dry season. The other side of the predictable variability, however, meant that large volumes of water usually would be collected during winter months enabling people with access to a cistern to allocate water intensive activities to this period, e.g. large scale dining gatherings or industrial activities. In a long perspective, societies may have adapted to the provision cycles of the cisterns, and activities such as large sacrifices at sanctuaries which required large volumes of water (e.g. in the sanctuary of Demeter and Kore at Corinth which relied on cisterns) may have taken place during the winter months. The presence and placement of a cistern could also have affected where activities could occur in a household, e.g. how the area around the cistern could be used. The presence of the cistern mouth must have meant that activities in the courtyard may have been physically restricted in terms of the uninterrupted area they could use. The 
presence of the opening may also have concentrated activities requiring water to the area, or individuals who simply found it convenient to spend time near the water source.

Our attempt to model the collected water volume in an ancient cistern and the available water volume in the cistern on a monthly basis is of course only a model, but it allows us to think about ancient cisterns in the way they probably functioned and to pose new research questions regarding the ancient water supply systems. In the current modelling, a major uncertainty is the issue of annual emptying of the cisterns. Running the model without the annual emptying of the cistern between October and November greatly affects the model results by increasing the available volume at any given point in time. From the modelling, it seems unlikely that cisterns were emptied at the end of the operative cycle if a large volume of water remained (or had accumulated again by early rains), both because removing the water would have represented a major effort and because the water could have been used to reduce the impact of a potentially dry incoming cycle. The advantage would be especially great in a situation with a precipitation pattern of alternating wet and dry years as seen in the period between 1979 and 1988 in our trial period (Figs. 4, 5). Whether postponing the cleaning to the next year happened is unknown, but if the quality of the water, or the idea of the quality of the water, heavily depended on the annual cleaning maybe it was a small sacrifice to empty several thousand litres of water to have access to less but clean, or perceived clean, water. It is, however, certain that all cisterns have to be cleaned at some point and maintenance cannot be postponed indefinitely. Further uncertainty is introduced to our modelling by, e.g. the volume of water used per person, the number of people using water and our use of modern rainfall data as a proxy for past variability. The individuals using the cisterns should also be expected to have been flexible in their consumption patterns adjusting after, e.g. the available volume in the cistern or knowledge about when the cistern may be replenished. One of the strengths of our modelling approach is that it offers a possibility to investigate easily different scenarios, for instance testing different consumption patterns. The results from running the model assuming a consumption of 51 per person per day highlight the benefits for a household to be able to reduce the consumption during a dry period, and it also highlights the potential importance of allowing flexible consumption in the model. However, the uncertainties that would be introduced by allowing flexible consumption in the model, mainly relating to the many unknowns in relation to consumption patterns in the past outweighs the benefits. Therefore, we remain with static consumption but have the possibility to test different consumption scenarios.

As long as climate reconstructions cannot provide us with monthly rainfall data, using modern rainfall data as a proxy for past rainfall is a prerequisite for this modelling. Even if the precise values may not be correct, a dry year or a series of consecutive dry years in the modern data function as an analogy for the same type of situation in the past, allowing us to understand the predictable variability that was the reality for a household relying on a cistern. However, it could be fruitful in the future to test different water supply scenarios based on different levels of precipitation amounts in relation to modern rainfall. This type of scenario building must also include other parts of the water supply system as well, e.g. if rainfall is assumed to be reduced by fifty percent in relation to modern times how does that affect the water table for wells and the flow in springs? Further studies should also take into account that cisterns seldom functioned in a vacuum in terms of water supply. Other sources were certainly used to complement the water from the cistern for various reasons. One important aspect is that the model does not account for industrial use, production of food stuffs for sale (e.g. baking bread commercially), or animal keeping. The model shows that such activities, many of which are economic in character, could not have been 
supported in the two test cases. Thus, the need for water beyond domestic use was supplied from other sources. It is, however, difficult to see the cisterns as the complement and not the other way around because of how they are located in the middle of the domestic setting.

Another important question which deserves further study is the extent to which the urban structure was adapted to cisterns rather than the other way around. It is likely that the decision to construct a cistern influenced how a building on the surface was constructed. The most obvious factor was the roof: a saddle roof (as often used in modern reconstructions, see e.g. Hoepfner 1999) would have been both technically more difficult to construct and less effective in terms of rainwater harvesting than a single sloping roof. It is therefore likely that buildings constructed in tandem with a cistern or after a cistern had a flat sloping roof in order to maximise the volume of water made available. Moreover, the roofs of buildings in which cisterns were constructed may have been remodelled when in need of repairs and reconstruction. In the same way other aspects of buildings and urban structures may have been affected by the presence of a cistern. Add to this that social tensions may have been sparked when some households had a reliable water supply through cisterns while others did not during droughts.

\section{Conclusions}

Cisterns were used over large parts of the ancient Greek world c. 400-50 BC, and together with e.g. wells and fountain houses they formed an intricate water supply system. The results in this paper have demonstrated the functionality, sustainability and reliability of cisterns as freshwater providers by RWH in the ancient water supply system. Our modelling results show that access to freshwater for a household was greatly enhanced if a cistern was present. We have also demonstrated the buffering capacities of the cisterns during occasional dry months, but more importantly during the dry season and in some cases also during prolonged periods of drought. This meant that having access to a cistern also meant increased water security. The sustainability and reliability of the cisterns is shown by how they made large volumes of water available even during the driest years. Indeed, cistern freshwater supply would need to be complemented from other sources during certain years, but overall having a cistern was a certain way to a secure water supply, especially if consumption was flexible. This is well illustrated by the scenario assuming a consumption of 51 per person per day, resulting in the cistern being empty by the end of the month in only 1 and $2 \%$ of the months in Dystos and Olynthos respectively.

Our study shows that the function of a cistern may be described by the term predictable variability, denoting how cisterns would not produce the same available water volume at regular intervals, but rather similar volumes following a predictable pattern. Moreover, the term highlights the certain uncertainty in the freshwater supply and the mitigating predictability of this uncertainty when relying on a cistern. This predictable variability is one important result of using detailed modern precipitation data in tandem with the ancient archaeological material. This predictable variability meant that cisterns had to be managed constantly in order to ensure that they neither overflowed (causing structural damage and introducing contaminants) nor ran dry, thus requiring what we call active participation.

The predictable variability, and thus accessible water supply, affected the function and use of cisterns. The available water volume shifted greatly both within and over cycles meaning that a domestic cistern could not have been used as a reliable water source for all 
year around industrial activities using water. Thus, the predictable variability of the cisterns affected how they could be used. The function and use of cisterns also impacted the social and physical structures around them. Since roofs formed the water collection surfaces, it is likely that these were adapted to produce a better water supply. In essence, there is good reason to believe that the physical forms of buildings were transformed by the presence of a cistern. Similarly, social patterns, e.g. movement both inside and outside of households, must have been affected by the presence of a water source in only some domestic houses.

This paper has contributed a better understanding of the role of cisterns in the ancient freshwater supply system. However, there is still much that needs to be explored if we want to understand how the ancient water supply worked as a whole and interactions of use between the various water sources at sites should also be discussed in greater depth than previously. This study of how RWH using cisterns contributed to the freshwater supply of ancient societies opens up a number of new research questions that hopefully can direct future studies increasing our knowledge of ancient societies in general and ancient water supply in particular. For instance, it would be interesting to address issues that relate to the size of the cisterns, why are the cisterns so large that they were normally not more than $50 \%$ filled? Can this be linked to social factors, economic potential, risk management or differences in climate? Future studies regarding how much water was used and how water usage varied due to different seasons and other factors such as special occasions and circumstances would also be very interesting. An important issue, with a clear bearing on the future-considering the projected changes in precipitation in the region-is how the use of cisterns affected societies during periods of droughts when not everyone had access to such installations and the freshwater they provide. Could cisterns have worked both as a stress relief and, at the same time, created social tensions? Although much work remains to unravel the ancient water supply system, this study has provided a first insight into how cisterns may have functioned in the past as providers of freshwater as well as to relieve water stress in semi-arid environments with highly variable precipitation.

Acknowledgements We thank two anonymous reviewers for their constructive comments that improved the quality of the manuscript. We would also like to thank the Department of Archaeology and Ancient History at Uppsala University where the study was produced, and in particular Angus Graham for making comments on a previous version of the manuscript. M.F. acknowledges funding from the Swedish Research Council (VR) Grant Number 421-2014-1181.

Open Access This article is distributed under the terms of the Creative Commons Attribution 4.0 International License (http://creativecommons.org/licenses/by/4.0/), which permits unrestricted use, distribution, and reproduction in any medium, provided you give appropriate credit to the original author(s) and the source, provide a link to the Creative Commons license, and indicate if changes were made.

\section{References}

Antoniou G, Xarchakou R, Angelakis AN (2006) Water cistern systems in Greece from Minoan to Hellenistic period. In: Angelakis AN, Koutsoyiannis D (eds) 1st IWA international symposium on water and wastewater technologies in ancient civilizations. Atlantis Hotel in Iraklio, Greece, 28-30 October 2006, Heraklion, pp 457-462

Antoniou G, Kathijotes N, Spyridakis DS, Angelakis AN (2014) Historical development of technologies for water resources management and rainwater harvesting in the Hellenic civilizations. Int J Water Resour Dev 30:680-693

Austin MM (2006) The Hellenistic world from Alexander to the Roman conquest. A selection of ancient sources in translation. Cambridge University Press, Cambridge 
Biernacka-Lubańska M (1977) A preliminary classification of Greek rainwater intakes. Archeologia 28:26-36

Biswas AK (1970) History of hydrology. North-Holland Publishing Company, Amsterdam, London

Boyd M (2015) Speleothems from warm climates: holocene records from the Caribbean and Mediterranean regions. Doctoral thesis, Department of Physical Geography, Stockholm University

Brinker W (1990) Wasserspeicherung in Zisternen. Ein Beitrag zur Frage der Wasserversorgung früher Städte. Leichtweiss-Institut für Wasserbau der Technischen Universität Braunschweig, Mitteilungen 109

Cahill N (2002) Household and city organization at Olynthus. Yale University Press, New Haven, London Camp J (1977) The water supply of ancient Athens from 3000 to 86 B.C. PhD thesis, Princeton University Collins M, Knutti R, Arblaster J, Dufresne J-L, Fichefet T, Friedlingstein P, Gao X, Gutowski WJ, Johns T, Krinner G, Shongwe M, Tebaldi C, Weaver AJ, Wehner M (2013) Long-term climate change: projections, commitments and irreversibility. In: Stocker TF, Qin D, Plattner G-K, Tignor M, Allen SK, Boschung J, Nauels A, Xia Y, Bex V, Midgley PM (eds) Climate change 2013: the physical science basis: contribution of working group I to the fifth assessment report of the intergovernmental panel on climate change. Cambridge University Press, Cambridge, New York, pp 1029-1136

Connelly JB, Wilson AI (2002) Hellenistic and Byzantine cisterns on Geronisos island. With a mortar analysis by C. Doherty. Report of the Department of Antiquities, Cyprus, pp 269-292

Crouch DP (1984) The Hellenistic water system of Morgantina, Sicily: contributions to the history of urbanization. Am J Archaeol 88:353-365

Dean JR, Jones MD, Leng MJ, Noble SR, Metcalfe SE, Sloane HJ, Sahy D, Eastwood WJ, Roberts N (2015) Eastern Mediterranean hydroclimate over the late glacial and Holocene, reconstructed from the sediments of Nar lake, central Turkey, using stable isotopes and carbonate mineralogy. Quat Sci Rev 124:162-174

Döll P (2009) Vulnerability to the impact of climate change on renewable groundwater resources: a globalscale assessment. Environ Res Lett 4:035006

Eastwood WJ, Leng MJ, Roberts N, Davis B (2007) Holocene climate change in the eastern Mediterranean region: a comparison of stable isotope and pollen data from Lake Gölhisar, southwest Turkey. J Quat Sci 22:327-341

Farreny R, Morales-Pinzón T, Guisasola A, Tayà C, Rieradevall J, Gabarell X (2011) Roof selection for rainwater harvesting: quantity and quality assessments in Spain. Water Res 45:3245-3254

Finné M, Holmgren K, Sundqvist HS, Weiberg E, Lindblom M (2011) Climate in the eastern Mediterranean, and adjacent regions, during the past 6000 years-a review. J Archaeol Sci 38:3153-3173

Finné M, Bar-Matthews M, Holmgren K, Sundqvist HS, Liakopoulos I, Zhang Q (2014) Speleothem evidence for late Holocene climate variability and floods in Southern Greece. Quat Res 81:213-227

Forbes RJ (1955) Studies in ancient technology, vol 1. Brill, Leiden

Garbrecht G (2001) Altertümer von Pergamon I:4. Stadt und Landschaft. Die Wasserversorgung von Pergamon. Walter de Gruyter, Berlin, New York

Glaser F (1983) Antike Brunnenbauten ( $\rho \eta v \alpha \imath$ in Griechenland). Verlag der Österreichischen Akademie der Wissenschaften, Wien

Hodge AT (2000a) Wells. In: Wikander Ö (ed) Handbook of ancient water technology. EJ Brill, Leiden, pp 29-33

Hodge AT (2000b) Aqueducts. In: Wikander Ö (ed) Handbook of ancient water technology. EJ Brill, Leiden, pp 39-65

Hoepfner W (1999) Die Epoche der Griechen. In: Hoepfner W (ed) Geschichte des Wohnens, 1. 5000 v.Chr. -500 n.Chr. Vorgeschichte, Frühgeschichte. Deutsche Verlags-Anstalt press, Stuttgart, pp 123-608

Keilholz P (2014) The ancient cisterns of Hellenistic Gadara/Umm Qais (Jordan). In: Schäfer T, Schön F, Gerdes A, Heinrichs J (eds) Antike und moderne Wasserspeicherung: Internationaler Workshop vom 11.-14.05.2011 in Pantelleria (Italien). VML, Verlag Marie Leidorf GmbH, Rahden/Westf, pp 27-36

Klaffenbach G (1954) Die Astynomeninschrift von Pergamon. Abhandlungen der Deutschen Akademie der Wissenschaften zu Berlin, vol 6. Akademie-Verlag, Berlin

Klingborg P (2017) Greek cisterns. Water and risk in ancient Greece, 600-50 BC. PhD thesis, Uppsala University

Kolbe W (1902) Die Astynomeninschrift. In von Prott H, Kolbe W (eds) Die Inschriften, Mitteilungen des Deutschen Archäologischen Instituts, Athenische Abteilung 27:47-77

Lange J, Husary S, Gunkel A, Bastian D, Grodek J (2012) Potentials and limits of urban rainwater harvesting in the Middle East. Hydrol Earth Syst Sci 16:715-724

Leng MJ, Wagner B, Boehm A, Panagiotopoulos K, Vane CH, Snelling A, Haidon C, Woodley E, Vogel H, Zanchetta G, Baneschi I (2013) Understanding past climatic and hydrological variability in the 
Mediterranean from Lake Prespa sediment isotope and geochemical record over the Last Glacial cycle. Quat Sci Rev 66:123-136

Luce JV (1971) The large house at Dystos in Euboea. Greece Rome 18:143-149

Mantellini S (2015) The implications of water storage for human settlement in Mediterranean waterless islands: the example of Pantelleria. Environ Archaeol 20:406-424

Masterman EWG (1918) Hygiene and disease in Palestine in modern and in Biblical times. Palest Explor Q 50:56-71

Mays LW (2010) A brief history of water technology during antiquity: before the Romans. In: Mays LW (ed) Ancient water technologies. Springer, Dordrecht, pp 1-28

Mays L, Antoniou GP, Angelakis AN (2013) History of water cisterns: legacies and lessons. Water 5:1916-1940

Roberts N, Jones MD, Benkaddour A, Eastwood WJ, Filippi ML, Frogley MR, Lamb HF, Leng MJ, Reed JM, Stein M, Stevens L, Valero-Garcés B, Zanchetta G (2008) Stable isotope records of Late Quaternary climate and hydrology from Mediterranean lakes: the ISOMED synthesis. Quat Sci Rev 27:2426-2441

Robinson DM (1946) Excavations at Olynthus XII. Domestic and public architecture. In: Robinson DM (ed) The John Hopkins University studies in archaeology, vol 36. The Johns Hopkins Press, Baltimore

Robinson DM, Graham JW (1938) Excavations at Olynthus VIII. The Hellenic house. A study of the houses found at Olynthus with a detailed account of those excavated in 1931 and 1934. The John Hopkins University studies in archaeology 25

Saba S (2012) The Astynomoi law from Pergamon. A new commentary. Die hellenistische Polis als Lebensform 6

Sazakli E, Alexopoulos A, Leotsinidis M (2007) Rainwater harvesting, quality assessment and utilization in Kefalonia Island, Greece. Water Res 41:2039-2047

Schick C (1878) Die Wasserversorgung der Stadt Jerusalem in geschichtlicher und topographischer Darstellung mit Originalkarten und Plänen. Z Dtsch Paläst Ver 1:132-176

Sparkes BA, Talcott L (1970) The Athenian Agora XII: black and plain pottery of the 6th, 5th and 4th centuries BC. Princeton, American School of Classical Studies

Thomas Th, Martinson DB (2007) Roofwater harvesting. A handbook for practitioners. International Water and Sanitation Centre, Technical Paper Series 49

UNESCO, World Water Assessment Programme (ed) (2012) Managing water under uncertainty and risk. Vol. 3: Facing the challenges. UNESCO, Paris

Van Liefferinge K (2013) Water use and management in the Classical and Early Hellenistic silver industry of Thorikos and the Laurion. Bull Antieke Beschav 88:109-126

Wellbrock K (2016) Die innerstädtische Wasserbewirtschaftung im hellenistisch-römischen Pergamon, 1st edn. Papierflieger Verlag GmbH, Clausthal-Zellerfeld

WHO (2011) Guidelines for drinking-water quality. Gutenberg, Geneva

Zanchetta G, Van Welden A, Baneschi I, Drysdale R, Sadori L, Roberts N, Giardini M, Beck C, Pascucci V, Sulpizi R (2012) Multiproxy record for the last 4500 years from Lake Shkodra (Albania/Montenegro). J Quat Sci 27:780-789

Patrik Klingborg received his PhD in Classical Archaeology and Ancient History at Uppsala University in May 2017. His research focus is on cisterns in ancient Greece with a broad interest in the water supply and the interaction between the water supply and the inhabitants, in the ancient world. Currently, he is developing a research project focused on long term changes to water supply systems in the ancient world.

Martin Finné is a researcher at the Department of Archaeology and Ancient History, Uppsala University. His main research focus is on paleoclimatology in southern Greece and the eastern Mediterranean. Since 2009, he has worked with reconstructing the climate and environment on the Peloponnese Peninsula using mainly cave speleothems (stalagmites) during the past 10,000 years. His research is also focused on the impact of climate and environmental variability on human societies on the Peloponnese as well as the human impact on the landscape. 